\title{
The Construction of Innovative and Entrepreneurial Teaching Ability of College Teachers
}

\author{
LIU Chao \\ Department of computer \\ Wuhan polytechnic \\ Wuhan 430074, China \\ 2093135999@qq.com
}

\begin{abstract}
Building a high-level team of innovative and entrepreneurial teachers is not only a prerequisite for improving college students' innovation and entrepreneurship ability, but also an important factor for ensuring the teaching quality of education. This paper expounds the knowledge and ability that innovative and entrepreneurial teachers should possess, and discusses the measures to improve and develop the teaching ability of innovative and entrepreneurial education of university teachers from education concept, evaluation and incentive, learning and training, teaching and scientific research, etc..
\end{abstract}

Keywords-innovation and entrepreneurship; college teachers; teaching ability; Build the countermeasure

\section{INTRODUCTION}

The key to innovation and entrepreneurship lies in talents, and talents mainly depend on the training of high-quality teachers in colleges and universities, which fully reflects the important status of college teachers in talent training. The innovation and entrepreneurship ability of college teachers affects the quality of education, which is an important guarantee for implementing education and an important way to improve students' innovation and entrepreneurship ability. Therefore, it is of great significance to strengthen the construction of education teaching capacity of university teachers.

\section{College INNOVATIVE ENTREPRENEURIAL TEACHERS SHOULD HAVE THE KNOWLEDGE AND ABILITY}

Education should be 'based on teaching entrepreneurial knowledge, with the training of entrepreneurial ability as the key and the cultivation of entrepreneurial spirit as the core". Therefore, as innovative and entrepreneurial teachers, we should pay attention to cultivating students' innovative thinking, deeply study and improve the training mechanism of innovative and entrepreneurial talents, teach them according to their aptitude, and cultivate high-level applied and innovative talents. The following are very important to train innovative and entrepreneurial teachers.

\section{A. Solid knowledge of innovation and entrepreneurship}

Education emphasizes the integration of theoretical knowledge and practice, and emphasizes the cultivation of innovation consciousness and entrepreneurial ability, which reflects the cross-integration of multiple disciplines. Therefore, innovative and entrepreneurial teachers should not only be familiar with the relevant laws, regulations and policies of innovation and entrepreneurship, but also have profound and solid theoretical knowledge and academic literacy, so as to stimulate students' entrepreneurial consciousness and spirit of innovation and effectively guide and guide college students.

\section{B. Rich experience in innovation and entrepreneurship}

Education focuses on the integration of theory and practice. Therefore, innovative entrepreneurial teachers should not only have solid theoretical knowledge, but also have strong practical operation ability. Teachers' high level of innovation and entrepreneurship practice ability is an important guarantee to improve college students' innovation and entrepreneurship practice ability. Practical and experienced teaching can timely and accurately identify problems in the process of innovation and entrepreneurship, and put forward effective Suggestions. At present, most college teachers lack the corresponding practical experience of innovation and entrepreneurship, and their practical ability is not high, so they cannot give targeted and planned guidance to the innovation and entrepreneurship activities of college students according to the actual situation of students.

\section{Innovation and entrepreneurship course development ability}

At present, most universities attach great importance to education for students' innovation and entrepreneurship, which has been included in the compulsory course of education for general education. The course is closely related to the major students have studied, which can not only stimulate students' enthusiasm for learning, develop their creative spirit, but also deepen students' understanding of this major. Therefore, when conditions permit, innovative and entrepreneurial teachers in colleges and universities should make full research on relevant majors and markets, develop innovative and entrepreneurial courses suitable for students of different majors, and improve the education effect of innovation and entrepreneurship. In addition to the teaching of theoretical courses, education also needs to organize various practical activities to stimulate students' innovative consciousness and enhance their practical ability. Through the in-class organization of teaching, stimulate the sparks of innovation; after class, I will guide students to write entrepreneurial plans and carry out entrepreneurial 
practices to turn creativity into reality. However, at present, teachers of innovation and entrepreneurship in large sectors of colleges and universities can only teach courses according to the book. They are not closely integrated with their majors and lack the necessary knowledge and skills of innovation and entrepreneurship.

\section{THE CONSTRUCTION OF INNOVATIVE AND}

ENTREPRENEURIAL TEACHING ABILITY OF COLLEGE TEACHERS

Teaching innovation ability is the embodiment of the highest level of teaching ability, which determines the cultivation of innovative talents to a certain extent. Therefore, it is logical and realistic to promote the development of teaching innovation ability of young teachers in colleges and universities.

\section{A. Renew traditional teaching thinking and strengthen the consciousness of innovation and entrepreneurship teaching}

To establish the correct education concept of innovation and entrepreneurship, we first need to break the traditional and inherent teaching thinking. If we cannot do this, we will simply follow the original teaching rules and repeat teaching, which will not achieve the cultivation of innovation ability and continuous improvement of teaching ability. College teachers should set up innovative and entrepreneurial concepts and strengthen the consciousness of innovative and entrepreneurial teaching. On the one hand, they should have the independent and conscious consciousness of teaching reform; on the other hand, they should cultivate their own sense of responsibility and enthusiasm in teaching and constantly update existing teaching concepts. At the same time, teachers also need to strengthen the attempt and practice of diversified teaching design, so that teaching can present diversified teaching patterns in the process of presupposition and generation, so as to form diversified understanding and thinking.

\section{B. We will improve the evaluation system and create an innovative atmosphere for teaching}

Colleges and universities should establish a scientific evaluation and incentive mechanism, give full play to the subjective initiative of teachers to carry out innovation and entrepreneurship education, and improve their enthusiasm and creativity. We will highlight teachers' ability to innovate in teaching and increase the incentives for teaching innovations. For example, teachers' teaching innovation ability practice activities are carried out in the school by means of subjects and open demonstration courses, and corresponding incentive and incentive mechanism is established to encourage teachers to carry out teaching innovation. Education examination of innovation and entrepreneurship is linked to professional title, salary, rewards and punishments, promotion, and it is given an appropriate tilt. At the same time, colleges and universities should create a cultural atmosphere that encourages teachers to innovate in teaching, form a subject-centered teaching community, strengthen teachers' consciousness of mutual guidance and cooperation, and make teaching innovation gradually become a conscious behavior in the process of communication and reflection.

\section{Independent learning and college training are combined to realize the integration of theory and practice}

Currently, college teachers generally lack the education background and background of education in innovation and entrepreneurship, and there are inherent deficiencies in the theory and practice of innovation and entrepreneurship, so that students want to start businesses but have no guidance, which will discourage students from starting businesses. Therefore, as college teachers, on the one hand, they should pay attention to improving their own theoretical knowledge and skills of entrepreneurship, understand entrepreneurial policies, update entrepreneurial knowledge, think and study ideas and methods of education innovation and entrepreneurship of college students, actively participate in lectures offered by experts and entrepreneurs, and enrich entrepreneurial theoretical knowledge. On the other hand, colleges and universities should provide individualized and targeted guidance and training according to teachers' different professional titles and professional backgrounds. Invite domestic and foreign related training organization system of professional training, invite relevant experts, scholars and entrepreneurs to make innovation business report, create conditions for them to participate in various business innovation education training and provide convenient, should pay attention to the development of the "production" project, to deeply enterprise experience practice platform for them, thus improve the pertinence and effectiveness of education innovation.

\section{Ability to transform innovative and entrepreneurial achievements}

Transformation of innovation results and transfer of technology are the biggest characteristics that distinguish entrepreneurial university from research university. Entrepreneurial universities generally set up technology transfer institutions such as technology licensing offices and technology licensing offices, and set up close governmentindustry-university cooperation mechanisms between government, enterprises and universities to help teachers achieve results transformation and transfer. Knowledge diffusion, application and knowledge marketization can be realized through various ways, and scientific research results can be transformed into products needed by the society, so as to realize the entrepreneurial function of the university. While focusing on the creation of innovative knowledge, entrepreneurial universities attach great importance to the transformation of results and technology transfer. Teachers should make full use of technology transfer institutions such as university technology licensing and authorization to realize the practical application of innovation research results. Teachers should be familiar with the achievements and the inherent law of technology transfer, into the market actively, strengthens the feasibility of transformation of technological achievements market analysis and forecast, increase economic efficiency for transformation of technical achievements and social benefit, rely on the power of market mechanism, actively promote the innovation research achievement transformation and technology transfer. 


\section{CONCLUSION}

Teachers of innovation and entrepreneurship in colleges and universities must have solid knowledge of innovation and entrepreneurship, rich practical experience of innovation and entrepreneurship, and the development ability of innovation and entrepreneurship courses. To build innovative and entrepreneurial teachers, it is necessary to renew teachers' traditional teaching thinking, improve the evaluation system, realize the integration of theory and practice, pay attention to the application of knowledge and transfer of technology, and promote the transformation of innovation results. Only in this way can we build innovative and entrepreneurial teachers.

\section{REFERENCES}

[1] Zhang Xian-rui, XI Ting-ting. The practical path of education in college innovation and entrepreneurship training for application-oriented talents[J]. Heilongjiang higher education research.2015(1):147.

[2] WANG Jun-sheng. Building an innovative country requires entrepreneurial universities[N]. Guangming daily,2013-11-05(03).

[3] GAO Cheng-hui, YANG Xiao-xiang. The research and practice of training high quality engineering science and technology talents in allround cooperation[J]. University teaching in China.2014(12).

[4] YANG Xin-ling. Four basic questions about entrepreneurial universities[J]. Higher education studies.2012,(12):59-64.

[5] YI Gao-feng. The connotation and benchmark of entrepreneurial university[J]. Modern education management.2013,(11):11-15.

[6] CHEN Xin-lui. Comparison of the main operating modes and characteristics of interdisciplinary organizations universities[J].Modern education science.2007,(5):88-94.

[7] SUN Ze-wen. Research on the characteristics, growth path and training mechanism of school innovative teachers[J].Higher education studies.2014,(3):11-15. 